\title{
Research in Journal Of Organization Design, 2012-2018
}

\author{
Charles C. Snow (1)
}

\author{
Correspondence: csnow@psu.edu \\ Professor Emeritus of Strategy and \\ Organization, The Pennsylvania \\ State University, 761 Spyglass Drive, \\ Eugene, OR 97401, USA
}

\begin{abstract}
Articles published in the Journal of Organization Design (JOD) from its inception in 2012 until mid-2018 are reviewed and summarized according to their type: research, point of view, translational, case study, research primer, and Organization Zoo. Using multiple assessment criteria, JOD's contributions to the field of organization design are identified. Important topics for future research on organization design are suggested.
\end{abstract}

Keywords: Organization design, Organization design theory and research, Organization design practice

This paper encompasses research published in the Journal of Organization Design from its initial volume in 2012 until June 2018. I begin by restating JOD's original aims and research domain. Then, I summarize the research according to JOD's article categories: research, point of view, translational, case study, research primer, and Organization Zoo. Lastly, I assess JOD's contributions to the field of organization design and suggest topics for future research.

\section{Aims and research domain}

JOD was established as an open access journal by the Organizational Design Community (www.orgdesigncomm.com) in 2011 and published its first volume in 2012. The overall aim of JOD was inspired by Herbert Simon's (1969) comments on design in his influential book, The Sciences of the Artificial: "The natural sciences are concerned with how things are. Design, on the other hand, is concerned with how things ought to be. Design is changing existing situations into preferred ones." Accordingly, JOD seeks papers that focus on the future (how organizations ought to be) and pertain to practice (how organizations can be re-designed and changed).

In the inaugural issue, the founding chief editors invited a group of prominent academics and practitioners to provide statements about the future of organization design (see Table 1). Collectively, those statements defined JOD's research domain and highlighted its relevant research methodologies:

- Expand the traditional focus on individual firms to include multi-firm networks, platforms, communities, and ecosystems

- Examine the implications of new enabling technologies for the design and management of organizations

- Increase involvement in the design process both internally and externally

(c) The Author(s). 2018 Open Access This article is distributed under the terms of the Creative Commons Attribution 4.0 International License (http://creativecommons.org/licenses/by/4.0/), which permits unrestricted use, distribution, and reproduction in any medium, provided you give appropriate credit to the original author(s) and the source, provide a link to the Creative Commons license, and indicate if changes were made. 
Table 1 Statements about the future of organization design (2012: vol. 1, issue 1)

\begin{tabular}{|c|c|}
\hline Statement & Observations and recommendations \\
\hline J.R. Galbraith & $\begin{array}{l}\text { Organization design will be shaped by three forces: process of concatenation, } \\
\text { Law of Requisite Variety, and enabling (largely digital) technologies. }\end{array}$ \\
\hline $\begin{array}{l}\text { J. Steinmetz, C. Bennett, } \\
\text { and D.D. Håkonsson }\end{array}$ & $\begin{array}{l}\text { Based on Royal Dutch Shell's scenario development, organization design must } \\
\text { address: (a) greater scope for the HR function, (b) talent management, (c) } \\
\text { continuous design processes, (d) external involvement in the design process, } \\
\text { (e) balance between global and local design projects, ( } f \text { ) assurance and compliance } \\
\text { requirements, and (g) stakeholder engagement. }\end{array}$ \\
\hline R.E. Miles & $\begin{array}{l}\text { Design is a critical management function and should be a product of an ongoing } \\
\text { dialogue between managers and academics. }\end{array}$ \\
\hline D.S. Alberts & $\begin{array}{l}\text { Given increasingly complex and dynamic environments, organization design must } \\
\text { (a) include agility as a component of organizational fitness, (b) broaden its focus to } \\
\text { include complex and temporary multi-actor enterprises, and (c) incorporate } \\
\text { mechanisms and processes of shared situation awareness. }\end{array}$ \\
\hline P. Puranam & $\begin{array}{l}\text { To advance as a field, organization design must (a) develop theories that aggregate } \\
\text { individual and group behavior in organizational contexts, (b) use research methods } \\
\text { such as experiments, simulations, and network techniques, and (c) develop } \\
\text { approaches for prototyping new designs before implementing them. }\end{array}$ \\
\hline C.Y. Baldwin & $\begin{array}{l}\text { The key challenge facing organization design in the future will be how to design } \\
\text { business ecosystems composed of self-governing corporations, individuals, and } \\
\text { communities. }\end{array}$ \\
\hline $\begin{array}{l}\text { M. Tushman, K.R. Lakhani, } \\
\text { and H. Lifshitz-Assaf }\end{array}$ & $\begin{array}{l}\text { Moving forward, the field of organization design must develop theories of how } \\
\text { organizations reshape their boundaries in order to innovate in complex, changing } \\
\text { environments. }\end{array}$ \\
\hline
\end{tabular}

- Expand organization design theory to include key components of effective designs such as agility and shared situation awareness

- Use research methods appropriate for exploring the future such as simulations, experiments, and prototyping.

Subsequent JOD issues and volumes contained articles in multiple formats, consistent with the chief editors' belief that authors should be offered a variety of ways to present their ideas, research findings, and prescriptions for practice. The original formats were research, point of view, translational, case study, and urgent issues. The urgent issues format was eliminated early on as it did not attract sufficient submissions to maintain it as a separate category. Similarly, JOD Live (videos) was discontinued after a few postings. Beginning in 2015, two new categories were introduced: research primer and the Organization Zoo series. All articles published in JOD's existing formats are reviewed below. (Periodically, the chief editors published editorial statements; those statements are not reviewed here.)

\section{Research articles}

During 2012-2018, JOD published 34 research articles. The contributions of these articles to organization design theory and practice are summarized in Table 2. Some general observations can be made about the research articles on organization design. First, the majority of the articles are conceptual: of the 34 articles, 26 are conceptual and eight are empirical (noted with asterisks in Table 2). Second, all the articles focus on theory, but most offer practical implications or recommendations as well. Third, nine articles explore the future of organizations while 25 deal with past situations. 
Table 2 Contributions of research articles

Study

Levitt (2012)

Mathews (2012)*

Waddell (2012)

Keinz, Hienerth, and Lettl (2012)

Gallo and Burton (2012)*

Luo and Donaldson (2013)*

Langer (2013)

DeWaard, Volberda, and Soeters (2013)

Kale and Puranam (2013)*

Turkulainen and Ketokivi (2013)*

Galbraith (2014)

Berner, Graupner, and Maedche (2014)

Grossman and Siegel (2014)

Koufteros, Peng, and Peters (2014)

Helfat and Karim (2014)*

Nissen (2014)

Cummings and Kiesler (2014)

Slinger and Morrison (2014)

Bøe-Lillegraven (2014)

de Waal and van der Heijden (2015)

Keers and van Fenema (2015)

Brix and Peters (2015)

Hunter (2015)*

Stea, Foss, and Foss (2015)

Bobbink, Hartmann, and Dewulf (2016)

Es-Sajjade and Wilkins (2017)

\section{Contribution}

Describes the evolution of enterprise organization designs and predicts the next emphasis to be big data

Illustrates how computational modeling can be used to extend the boundaries of organization design theory

Discusses how supra-firm industrial structures affect firms' economic performance

Discusses how global action networks can address global social challenges

Discusses organization designs for user-centered, open innovation processes

Presents a simulation study of how an organization should respond to an environmental shock

Identifies specific conditions under which information processing can compensate for misfit

Describes a process for organizations to assimilate young talent from underserved populations

Identifies modular organizing and organizational sensing as main drivers of organizational responsiveness

Examines how inter-firm relationships are and ought to be designed

Examines the mechanisms that link organizational integration to organizational effectiveness

Discusses the activities of leading-edge firms in developing a big data analytics capability

Discusses how big data requires the transformation from command and control hierarchies to post-bureaucratic organizational structures

Presents a framework for determining how analytics capability should be distributed within an organization

Examines the effects of organization structure on cross-functional, supplier, and customer integration

Presents a normative theory in which the effectiveness of organization design and redesign depends on the characteristics of organizational routines

Discusses the concept of organizational fit in dynamic environments

Applies organization theory to the scientific endeavors of public and private research organizations

Argues that big data will change organization structures but not organization design processes

Examines exploration and exploitation activities in the newspaper industry in order to determine the main causal factors of firm performance

Investigates the role performance management plays in creating and maintaining a high-performance organization

Explores the role of stakeholder values management on interorganizational design

Presents a case study of how a high-uncertainty innovation project induced changes in the organization's design

Compares the information processing and social network perspectives on organization structure and its relation to firm performance

Discusses the relationship between organization design and managerial delegation

Discusses the role of organization design in forming inter-organizational collaborations

Uses social interdependence theory to examine how design shapes behavior and how behavior influences design 
Table 2 Contributions of research articles (Continued)

\begin{tabular}{ll}
\hline Study & Contribution \\
\hline Snow, Fjeldstad, and Langer (2017) & $\begin{array}{l}\text { Provides a conceptual framework for the design of digital organizations } \\
\text { Koch and Windsperger (2017) }\end{array}$ \\
Heine and Kerk (2017) & $\begin{array}{l}\text { Presents a network-centric framework that helps firms design strategies } \\
\text { Discusses the role of arbitration in resolving conflicts in inter- } \\
\text { organizational processes } \\
\text { Kevelops a conceptual model of transitioning from an economic cluster } \\
\text { to a collaborative community }\end{array}$ \\
Gaim et al. (2018) & $\begin{array}{l}\text { Develops a classification scheme for comparing competing demands } \\
\text { in organizations }\end{array}$ \\
Burton and Obel (2018) & $\begin{array}{l}\text { Argues for a science-based theory of organization design that relies } \\
\text { heavily on observation and experimentation }\end{array}$ \\
Kang et al. (2018)* & $\begin{array}{l}\text { Discusses the role of uncertainty and controversy in the theory of the } \\
\text { firm }\end{array}$ \\
\hline
\end{tabular}

*Empirical article

\section{Point of view articles}

A point of view article adopts a particular perspective and applies it to a design problem or organizational situation. For example, Levitt and Eriksson (2016) adopt the perspective of public-private partnerships and develop a governance model of infrastructure service delivery. During 2012-2018, JOD published 19 point of view articles. These articles are summarized in Table 3 according to the perspective taken and the contribution to organization design theory or practice.

Point of view articles are difficult to evaluate in terms of their contribution to the theory or practice of organization design. As indicated in Table 3, many different perspectives are represented, and none of the articles presents empirical data. Therefore, whatever its message, the typical point of view article is subjective and its contribution lies in the eyes of the beholder. Ten of the 19 articles are related to theory and nine are related to practice.

\section{Translational articles}

A translational article takes an existing concept or theory and derives its theoretical or practical implications for organization design. For example, Teece and Linden (2017) apply the concept of business model to the digital environment and derive its implications for the design of digitized organizations. During 2012-2018, JOD published seven translational articles. These articles are summarized in Table 4 according to the translational item and its implications for the theory or practice of organization design.

The true measure of whether a translational article has made a contribution to the field of organization design lies in the subsequent use of the translated concept or theory to improve the design or management of organizations. Arguably, it may be too early to see any of these translational articles being used either in theory building or in practice.

\section{Case studies}

A case study article is based on the experiences of a single organization, and this versatile format can be used to introduce a new concept, refine an existing theory 
Table 3 Contributions of point of view articles

\begin{tabular}{|c|c|c|}
\hline Study & Perspective & Contribution \\
\hline $\begin{array}{l}\text { Miles and Scaringella } \\
\text { (2012) }\end{array}$ & $\begin{array}{l}\text { A "futures group" within an } \\
\text { organization (or spanning } \\
\text { multiple organizations) }\end{array}$ & $\begin{array}{l}\text { A futures group can help a firm synchronize market } \\
\text { and technology development }\end{array}$ \\
\hline Levitt (2012) & $\begin{array}{l}\text { Agent-based computational } \\
\text { simulation }\end{array}$ & $\begin{array}{l}\text { Recommends greater use of computational modeling } \\
\text { and simulation in organization design }\end{array}$ \\
\hline Ketchen et al. (2012) & Supply chain & $\begin{array}{l}\text { Suggests five ways supply chain performance can be } \\
\text { improved }\end{array}$ \\
\hline $\begin{array}{l}\text { Caspin-Wagner et al. } \\
\text { (2013) }\end{array}$ & Interdependencies fit & $\begin{array}{l}\text { Organizational performance can be improved by } \\
\text { managing internal and external fit }\end{array}$ \\
\hline Burton (2013) & $\begin{array}{l}\text { Summary of first ODC Annual } \\
\text { Conference }\end{array}$ & $\begin{array}{l}\text { Three themes: (1) there are clear fundamentals of } \\
\text { organization design, ( } 2 \text { ) focus needs to expand } \\
\text { beyond that of the individual firm, and ( } 3 \text { ) how } \\
\text { organizations can become more agile }\end{array}$ \\
\hline Yonatany (2013) & $\begin{array}{l}\text { Organizational platform/ } \\
\text { ecosystem }\end{array}$ & $\begin{array}{l}\text { Develops a model explaining why and where } \\
\text { platform/ecosystems exist }\end{array}$ \\
\hline $\begin{array}{l}\text { Plump and Ketchen } \\
\text { (2013) }\end{array}$ & Virtual team & Identifies potential legal pitfalls of virtual teams \\
\hline Miller (2014) & $\begin{array}{l}\text { University-industry } \\
\text { partnerships }\end{array}$ & $\begin{array}{l}\text { Identifies collaborative approaches that could be used } \\
\text { to close the big data skills gap }\end{array}$ \\
\hline Korhonen (2014) & Requisite organization & $\begin{array}{l}\text { A new tool for determining organizational complexity } \\
\text { in both strategy and structure }\end{array}$ \\
\hline $\begin{array}{l}\text { Plump and Ketchen } \\
\text { (2014) }\end{array}$ & Franchising & $\begin{array}{l}\text { How organizations can benefit from increased } \\
\text { accountability and even benefit from it }\end{array}$ \\
\hline Hertz (2015) & $\begin{array}{l}\text { Baldrige Performance } \\
\text { Excellence Program }\end{array}$ & Changing guidelines for business excellence \\
\hline $\begin{array}{l}\text { Giustiniano } \\
\text { and D'Alise (2015) }\end{array}$ & Inter-organizational designs & Role of design in networks, clusters, and small worlds \\
\hline Huber (2016) & U.S. companies' structure & $\begin{array}{l}\text { Identifies changes in business environment that are } \\
\text { dangerous to traditional U.S. companies and changes } \\
\text { in structure of new U.S. companies that are dangerous } \\
\text { to society }\end{array}$ \\
\hline $\begin{array}{l}\text { Levitt and Eriksson } \\
\text { (2016) }\end{array}$ & Public-private partnership & $\begin{array}{l}\text { Presents a governance model of infrastructure } \\
\text { service delivery based on Australian experience }\end{array}$ \\
\hline $\begin{array}{l}\text { Håkonsson } \\
\text { and Carroll (2016) }\end{array}$ & Big data & Describes problems and opportunities of big data \\
\hline $\begin{array}{l}\text { Dong, March, and } \\
\text { Workiewicz (2017) }\end{array}$ & Interview of James G. March & $\begin{array}{l}\text { Key insights about organizations and organization } \\
\text { design based on March's work }\end{array}$ \\
\hline Kutz (2017) & $\begin{array}{l}\text { Double-bind communications } \\
\text { in organizations }\end{array}$ & $\begin{array}{l}\text { Negative consequences of double-bind } \\
\text { communications to employees and organizations }\end{array}$ \\
\hline $\begin{array}{l}\text { Ebert and Freibichler } \\
\text { (2017) }\end{array}$ & Nudge management & $\begin{array}{l}\text { How to increase knowledge worker productivity } \\
\text { through nudge management }\end{array}$ \\
\hline Yonatany (2017) & $\begin{array}{l}\text { Platform-ecosystem } \\
\text { organizations }\end{array}$ & $\begin{array}{l}\text { Identifies competitive advantages of this form in a } \\
\text { highly digitized environment }\end{array}$ \\
\hline
\end{tabular}

or concept, demonstrate an application, describe a new organization design, present an unusual or complex design problem in need of analysis, and so on. During 2012-2018, JOD published 11 case studies (see Table 5).

The specific contributions of the 11 case studies are shown in the table. Each of the cases makes a unique contribution, reaffirming the versatility and value of the case study format. Three case studies focused on the future, and eight analyzed phenomena that occurred in the past. All 11 case studies presented practical implications or recommendations. 
Table 4 Contributions of translational articles

\begin{tabular}{|c|c|c|}
\hline Study & Translational item & Implications \\
\hline Carroll (2012) & Exploration-exploitation & $\begin{array}{l}\text { All organizations face the challenge of making investments } \\
\text { in two very different sets of activities: exploration and } \\
\text { exploitation. Four solutions to this challenge are discussed: } \\
\text { outsourcing, separation, cycling back and forth, and } \\
\text { continuous incremental reconfiguration. }\end{array}$ \\
\hline $\begin{array}{l}\text { Liedtka and Parmar } \\
\text { (2012) }\end{array}$ & Reflective practitioner & $\begin{array}{l}\text { To improve the implementation of a particular design, } \\
\text { managers can practice "designing" by generating problem } \\
\text { frames as hypotheses, and then testing and refining those } \\
\text { hypotheses in the situation }\end{array}$ \\
\hline $\begin{array}{l}\text { Christensen and } \\
\text { Knudsen (2013) }\end{array}$ & $\begin{array}{l}\text { Visual representation of } \\
\text { organizational decision } \\
\text { flows }\end{array}$ & $\begin{array}{l}\text { By showing how fundamental properties of decisions can } \\
\text { be derived from visual representation, a four-step method } \\
\text { to analyze organizational performance emerges: visualize, } \\
\text { enumerate, aggregate, compare }\end{array}$ \\
\hline $\begin{array}{l}\text { Donaldson and } \\
\text { Joffe }(2014)\end{array}$ & Fit & $\begin{array}{l}\text { Uses the concept of fit to show how to align organizational } \\
\text { designs to three important situational factors: competitive } \\
\text { strategy, organization size, and task uncertainty }\end{array}$ \\
\hline $\begin{array}{l}\text { Kates and Kesler } \\
\text { (2015) }\end{array}$ & Activation & $\begin{array}{l}\text { Applying the concept of activation in a global context, five } \\
\text { activators of a company's global operating model are } \\
\text { discussed }\end{array}$ \\
\hline $\begin{array}{l}\text { Burton, Obel, and } \\
\text { Håkonsson (2015) }\end{array}$ & Matrix organizing & $\begin{array}{l}\text { Translating the concept of matrix organizing into action, } \\
\text { three conditions necessary for a matrix to work are } \\
\text { identified: strong purpose, alignment among major } \\
\text { contingency variables, and management of junctions }\end{array}$ \\
\hline $\begin{array}{l}\text { Teece and Linden } \\
\text { (2017) }\end{array}$ & Digital business model & $\begin{array}{l}\text { Develops the implications of the business model concept } \\
\text { in a digital environment }\end{array}$ \\
\hline
\end{tabular}

\section{Research primers}

A research primer introduces readers to a specific research stream or literature and articulates implications for organization design theory and practice. The first research primer, on multimarket competition, was published in 2015, and three more primers, on divestitures, evolutionary psychology, and post-merger integration, have been published since then. The contributions of the four primers are summarized in Table 6 .

All four primers offer insights into organization design in the Simon (1969) sense: how organizations "ought to be" and how they can be changed from "existing situations into preferred ones." The primer on multimarket competition alerts us to the fact that nominally independent firms are connected by multiple points of contact in the marketplace, and their respective designs must address the tensions that result. Divestiture involves the removal of one or more businesses from the portfolio of a diversified firm, and the firm must be redesigned for a reduced scope of operations. The evolutionary psychology primer argues that many existing organizations are too complex for their members to cope psychologically, and it challenges organizational researchers and designers to find ways to transform those existing situations into preferred ones. The primer on post-merger integration discusses how an acquiring firm and a target firm ought to combine their resources and how the two organizations can be designed into one.

\section{Organization Zoo}

The Organization Zoo focuses on outliers: new, unusual, or rare species of organizations. Each Organization Zoo article addresses a single organization, analyzing its features and behavior in the interest of understanding it. After the case is introduced, expert commentators offer their views, and a richer, more colorful picture of the 
Table 5 Contributions of case studies

\begin{tabular}{|c|c|c|}
\hline Study & Case & Contribution \\
\hline Beer (2013) & $\begin{array}{l}\text { HP's Santa Rosa Systems } \\
\text { Division }\end{array}$ & $\begin{array}{l}\text { Strategic Fitness Model is introduced to the } \\
\text { field }\end{array}$ \\
\hline Valikangas and Romme (2013) & Large U.S.-based retailer & $\begin{array}{l}\text { Examines the concept of organizational } \\
\text { resilience }\end{array}$ \\
\hline $\begin{array}{l}\text { Engler, Jones, and Van de Ven } \\
\text { (2013) - this case includes four } \\
\text { commentaries. }\end{array}$ & Ascension Health & $\begin{array}{l}\text { Describes a process for enacting organizational } \\
\text { designs suitable for the dynamic healthcare } \\
\text { sector }\end{array}$ \\
\hline Gabel and Tokarski (2014) & RTI International & $\begin{array}{l}\text { Discusses how this non-profit research } \\
\text { organization is dealing with the challenges } \\
\text { of big data }\end{array}$ \\
\hline Schroeder and DeNoble (2014) & SOLO Eyewear & How to design a triple bottom line company \\
\hline Hossain and Kauranen (2014) & X Prize Foundation & $\begin{array}{l}\text { Describes a competition-based process for the } \\
\text { development of innovations }\end{array}$ \\
\hline Casalini, Fioretti, and Pyka (2016) & iPLON & $\begin{array}{l}\text { Develops a novel interpretive framework for } \\
\text { looking at the technology of foolishness }\end{array}$ \\
\hline Camuffo and Wilheim (2016) & Toyota Motor Company & $\begin{array}{l}\text { Describes internal processes that resulted in } \\
\text { external misfit }\end{array}$ \\
\hline Worren (2017) & $\begin{array}{l}\text { FMC Subsea Division of } \\
\text { TechnipFMC }\end{array}$ & $\begin{array}{l}\text { Describes how the matrix structure can } \\
\text { sometimes be a transitory form }\end{array}$ \\
\hline Jordan (2017) & Uber & $\begin{array}{l}\text { Suggests four key principles for designing large- } \\
\text { scale digital organizations }\end{array}$ \\
\hline Luo et al. (2018) & $\begin{array}{l}\text { Large Chinese } \\
\text { multinational firm }\end{array}$ & $\begin{array}{l}\text { Describes the transition from a hierarchical } \\
\text { manufacturing organization to an open platform } \\
\text { organization }\end{array}$ \\
\hline
\end{tabular}

organization emerges. To date, the Organization Zoo series contains two articles: Valve Corporation and GitHub. These articles are summarized in Table 7.

The main value of cases in the Organization Zoo series is the discussion and debate they engender. Each of these two cases is especially interesting in various ways. Both Valve and GitHub are "boss-less" organizations in the sense that they rely on self-organizing rather than hierarchical mechanisms for control and coordination. After operating for 7 years without a hierarchy, GitHub, for several reasons, decided to install one. Expert commentators are invited to analyze such moves as well as other organizational features and

Table 6 Contributions of research primers

\begin{tabular}{|c|c|c|}
\hline Study & Topic & Contribution \\
\hline $\begin{array}{l}\text { Sengul and Dimitriadis } \\
\text { (2015) }\end{array}$ & Multimarket competition & $\begin{array}{l}\text { Identifies various tensions inside a firm caused by } \\
\text { multimarket competition (e.g., between headquarters } \\
\text { and subsidiaries) and discusses how organizations can } \\
\text { be designed to address them }\end{array}$ \\
\hline $\begin{array}{l}\text { Feldman and McGrath } \\
\text { (2016) }\end{array}$ & Divestitures & $\begin{array}{l}\text { Discusses the implications of divestitures for } \\
\text { organization design }\end{array}$ \\
\hline Van Vugt (2017) & Evolutionary psychology & $\begin{array}{l}\text { Many features of modern organizations exhibit large } \\
\text { mismatches with human psychology as it has evolved } \\
\text { from small-scale societies. By studying } \\
\text { evolutionary psychology, researchers and designers } \\
\text { can develop designs that reduce such mismatches. }\end{array}$ \\
\hline $\begin{array}{l}\text { Bodner and Capron } \\
\text { (2018) }\end{array}$ & Post-merger integration & $\begin{array}{l}\text { Mergers and acquisitions combine the resources } \\
\text { of two organizations into one. By combining the } \\
\text { resource reconfiguration perspective with the } \\
\text { structural organization design perspective, future } \\
\text { research directions on post-merger integration are } \\
\text { generated. }\end{array}$ \\
\hline
\end{tabular}


Table 7 Contributions of the Organization Zoo

\begin{tabular}{|c|c|}
\hline Study & Contribution \\
\hline Puranam and Håkonsson (2015) & $\begin{array}{l}\text { Valve Corporation, a gaming company, does not use a formal hierarchy for } \\
\text { control and coordination. Seven commentaries on this case explore what a } \\
\text { "boss-less" company means for organization theory and design. }\end{array}$ \\
\hline Burton et al. (2017) & $\begin{array}{l}\text { GitHub, a software company, operated for } 7 \text { years without a hierarchy. Suddenly, } \\
\text { it installed one. Four commentaries examine the role of hierarchy in } \\
\text { organizations. }\end{array}$ \\
\hline
\end{tabular}

managerial processes. The total package of a Zoo case and its commentaries is a rich mix of theory, practice, and opinions about organization design.

\section{JOD's contributions to the field of organization design}

JOD is the only peer-reviewed academic journal focused entirely on organization design. Its very existence, therefore, constitutes a contribution to the field. In addition, JOD's contribution is notable in that it seeks to add to our knowledge about both theory and practice. JOD is an open access journal, so the ideas, concepts, studies, and recommendations it provides are freely available to everyone.

JOD has also made contributions to the field of organization design as envisioned by Simon (1969) - that is, a focus on how organizations ought to be and how they can be changed from their existing forms into preferred ones. Of the more than 100 articles published in JOD to date, 12 reflect a focus on the future and 23 examine how organizations can be redesigned and changed. Although these numbers are not large, JOD appears to be on its way to developing the normative science that the field of organization design requires.

Lastly, JOD's contributions to the field can be assessed using the statements about the future of organization design that were published in the first issue.

1. Expand the traditional focus on individual firms to include multi-firm networks, platforms, communities, and ecosystems. JOD has published a number of articles about "supra-firm" forms of organizing such as global action networks, supply chains, extended enterprises, platforms, user-driven innovation processes, collaborative communities, business ecosystems, and the modularization of industries.

2. Examine the implications of new enabling technologies for the design and management of organizations. Articles published in JOD have examined the following enabling technologies and their implications for organization design: virtual team design, crisis response, visual representation of decision flows, big data analytics, crowdsourcing, technology of foolishness, digital technologies, and nudge management.

3. Increase involvement in the design process both internally and externally. There have been only a few articles published in JOD that focus on the design process.

Increased internal involvement has been advocated through autonomous teams, virtual design teams, and a futures group. The most thorough description of increased external involvement in the design process is the case study of Ascension Health.

4. Expand organization design theory to include key components of effective designs such as agility and shared situation awareness. Several articles have suggested that new variables be added to organization design theory or have emphasized the 
importance of certain factors in existing or emerging designs, including resilience, power laws, responsiveness, design thinking, big data, and delegation. In each of those articles, the variable or factor has been discussed but not integrated into a broader theory of design.

5. Use research methods for exploring the future such as simulations, experiments, and prototyping. Of all the articles published in JOD, only two involve simulation and one involves prototyping. There are no articles involving experiments. Clearly, articles based on these three recommended methods for exploring the future are lacking in JOD.

\section{Future research topics}

Because JOD is a journal focused exclusively on advancing the theory and practice of organization design, any design-related paper that, in the judgment of peer reviewers, adds to the scientific record is a contribution to the field. Now in its seventh year of publication, JOD has published more than 100 articles. This is a much larger body of knowledge on organization design than would otherwise be available without JOD.

Looking forward, and viewing JOD from the standpoint of a former chief editor, I would like to see JOD make greater strides in honoring Simon's (1969) original vision of design. That vision had two underlying thoughts: (1) a focus on the future, or what organizations could and should be, and (2) a practical concern with how designers (along with managers and change-agents) can turn existing situations into preferred ones. Research topics reflecting an orientation towards the future should include the sources and shapes of new organizational forms, the implications of emerging technologies for the design and management of organizations, the nature and effectiveness of collaboration both within and across organizations, and an expanded theory of organization design that incorporates important variables such as agility and shared situation awareness. Topics of re-design and change should include the role of design thinking in change management, internal and external stakeholder involvement in the design process, and case studies demonstrating the application and results of change process models.

It would be especially heartening to see more articles in JOD that employ research methodologies well suited to organization design, namely simulations, experiments, and prototyping. In designing modern organizations, where human and digital actors increasingly collaborate with one another, there are abundant opportunities to conduct research studies that combine concepts and methods of simulation, machine learning, augmented reality, and video games.

\section{Conclusions}

JOD is the only academic journal focused exclusively on the topic of organization design. It seeks to bridge the gap between scholars and practitioners, and it offers authors multiple formats to publish their work. Now in its seventh year of publication, JOD is firmly established in the organizational sciences. Going forward, hopefully JOD will put even greater emphasis on the future of organizations and the improvement of management practice. 
Availability of data and materials

The data for this article come from the Journal of Organization Design and are freely available.

\section{Author's contributions}

I prepared the manuscript by myself. I have read and approved the final version of the manuscript.

\section{Consent for publication}

The content of the manuscript has not been published, or submitted for publication, elsewhere.

\section{Competing interests}

The author declare that he have no competing interests.

\section{Publisher's Note}

Springer Nature remains neutral with regard to jurisdictional claims in published maps and institutional affiliations.

Received: 6 July 2018 Accepted: 12 August 2018

Published online: 10 September 2018

References

Levitt RE, Eriksson K (2016) Developing a governance model for PPP infrastructure for service delivery based on lessons from eastern Australia. J Org Design 5:7

Simon HA (1969) The sciences of the artificial. MIT Press, Cambridge

Teece DJ, Linden G (2017) Business models, value capture, and the digital enterprise. J Org Design 6:8

Submit your manuscript to a SpringerOpen ${ }^{\circ}$ journal and benefit from:

- Convenient online submission

- Rigorous peer review

- Open access: articles freely available online

- High visibility within the field

- Retaining the copyright to your article 